\title{
Pengelolaan kelas pada praktik pengalaman lapangan (PPL) pendidikan profesi guru (PPG) prajabatan bidang studi bahasa Indonesia di SMA Negeri 7 Malang
}

\section{Gigit Mujianto ${ }^{I^{*}}$, Sudjalil ${ }^{2}$}

Pendidikan Bahasa Indonesia, Fakultas Keguruan dan Ilmu Pendidikan, Universitas Muhammadiyah Malang, Jalan Raya Tlogomas 246 Malang, Indonesia.

Igigit@umm.ac.id"; sudjali1_63@yahoo.com²

*Corresponding author: gigit@umm.ac.id

\begin{abstract}
Sejarah Artikel Diterima: 20 September 2020 Direvisi: 20 Oktober 2020 Tersedia Daring: 3I Oktober 2020 ABSTRAK

Strategi pengelolaan kelas membutuhkan kompetensi komunikatif guru dalam menciptakan dan mempertahankan suasana (kondisi) kelas agar kegiatan pembelajaran dapat berlangsung secara efisien. Penelitian ini bertujuan untuk mengetahui teknik, strategi, dan teknik pengelolaan kelas pada Praktik Pengalaman Lapangan (PPL) Pendidikan Profesi Guru (PPG). Penelitian ini merupakan penelitian deskriptif kualitatif. Data dan sumber data dalam penelitian ini berupa catatan lapangan deskriptif dan reflektif, sumber data berupa interaksi guru dan peserta didik dalam proses pembelajaran di kelas. Data dikumpulkan dengan menggunakan instrumen observasi dan dokumentasi. Data yang telah diperoleh kemudian dianalisis berdasarkan model Miles dan Huberman. Hasil penelitian menunjukkan bahwa teknik, strategi, dan teknik pengelolaan kelas terlihat dalam tiga kegiatan pembelajaran yang terdiri dari kegiatan awal, kegiatan inti, dan kegiatan penutup pembelajaran. Secara umum dapat disimpulkan bahwa dalam melaksanakan kegiatan pengelolaan kelas guru selalu menggunakan teknik, strategi, dan teknik pengelolaan kelas yang bervariasi di kegiatan awal, kegiatan inti, dan kegiatan akhir pembelajaran.

Kata Kunci Pendidikan profesi guru, Pengelolaan kelas, Praktik pembelajaran lapang

\section{ABSTRACT}

Classroom management strategies require teachers' communicative competence in creating and maintaining an encouraging classroom atmosphere so that learning activities can take place efficiently. This study aimed at determining the techniques, strategies, and classroom management techniques employed by student teachers of Teacher Professional Education (PPG) program during their Field Experience Practice (PPL) for. This research used a qualitative descriptive approach. The data were descriptive and reflective field notes. The data sources were in forms of the interaction between teachers and students in the classroom learning process. The data were collected using observation and documentation instruments. The obtained data were then analyzed using the Miles and Huberman model. The results showed that techniques, strategies, and classroom management techniques were indicated in three learning activities consisting of initial activities, core activities, and closing activities. It can be concluded that the teachers always use various classroom management techniques, strategies, and techniques in the initial activities, core activities, and final activities of learning.
\end{abstract}

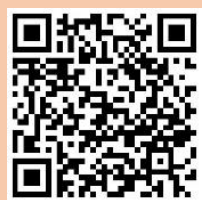

Copyright@2020, Gigit Mujianto \& Sudjalil This is an open access article under the CC-BY-3.0 license

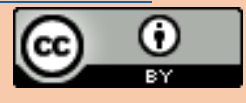

\begin{tabular}{ll}
\hline Keywords & Classroom management, Field learning practice, Teacher professional education \\
\hline How to Cite & Mujianto, G., \& Sudjalil, S. (2020). Pengelolaan kelas pada Praktik Pengalaman Lapangan (PPL) \\
& $\begin{array}{l}\text { Pendidikan Profesi Guru (PPG) prajabatan bidang studi bahasa Indonesia di SMA Negeri } 7 \\
\text { Malang. KEMBARA: Jurnal Keilmuan Bahasa, Sastra, dan Pengajarannya (e-Journal), 6(2), 255-265. } \\
\text { doi: https://doi.org/I0.22219/kembara.v6i2.I4057 }\end{array}$ \\
\hline \hline
\end{tabular}

\section{PENDAHULUAN}

Dalam UU Guru dan Dosen, UU No.I4 tahun 2005, guru didefinisikan sebagai pendidik profesional dengan tugas utama mendidik, mengajar, membimbing, mengarahkan, melatih, menilai, dan mengevaluasi peserta didik pada pendidikan anak usia dini jalur pendidikan formal, pendidkan dasar, dan pendidikan menengah (Sudjalil \& Mujianto, 2017). Peran penting seorang guru sebagai pendidik sangat besar untuk memilih serta melaksanakan pembelajaran yang efisien bagi peserta didik di dalam kelas (Maghfiroh, 2019; Saputra, 2015), sehingga membuat peserta didik merasa nyaman dalam mengikuti proses pembelajaran (Habiburrahman, 2015), serta membuat peserta didik lebih memahami pembelajaran 
yang telah disampaikan (Daryanto, 2016). Dalam hal ini, memilih dan melaksanakan pembelajaran yang efisien bagi peserta didik di dalam kelas berkenaan dengan kemampuan guru dalam mengelola kelas (Hendriana, 2018), yaitu bagaimana upaya guru dalam menciptakan dan mempertahankan suasana (kondisi) kelas agar kegiatan pembelajaran dapat berlangsung secara efisien (Yumnah, 2018).

Menurut Ramli (20I5) pengelolaan kelas adalah upaya yang dilaksanakan guru dalam mengelola anak didiknya di kelas dengan menciptakan atau mempertahankan suasana atau kondisi kelas yang mendukung program pengajaran untuk mencapai tujuan yang telah ditetapkan. Prosedur pengelolaan kelas pada intinya dimaksudkan untuk mengurangi kesempatan kekacauan, keributan, kebosanan, dan gangguan (Mustofa, 2019). Oleh sebab itu, seorang guru harus memiliki kompetensi pengelolaan kelas yang baik, sehingga akan tercipta suasana belajar yang menarik, menyenangkan untuk mencapai tujuan pengajaran dan meningkatkan kualitas pembelajaran (Zahroh, 2015), serta menciptakan, memelihara dan mengendalikan kondisi belajar yang optimal bagi terciptanya proses belajar mengajar yang efektif (Minsih, 2018). Selain itu, dapat membangun hubungan sosio emosional (hubungan interpersonal) yang baik antara guru dengan peserta didik, serta antara peserta didik dengan guru (Isbadrianingtyas, Hasanah, \& Mudiono, 2016). Pembelajaran secara efektif dapat dilakukan melalui pengelolaan kelas yang baik. Mengelola kelas merupakan faktor yang dapat menciptakan dan mempertahankan suasana kelas agar selalu efektif (Aliyyah \& Abdurakhman, 2016). Kelas dapat menjadi tempat dimana kurikulum pendidikan dengan segala komponennya, materi dengan sumber pelajarannya, serta segala pokok bahasan mengenai materi itu diajarkan dan ditelaah ulang di dalam kelas (Faruqi, 2018; Warsono, 2016; Zahroh, 2015).

Puspitaningdyah (2018) mengemukakan pengelolaan kelas menunjukkan lebih pada kegiatankegiatan yang menciptakan dan mempertahankan kondisi yang optimal bagi terjadinya proses belajar. Pengelolaan kelas merupakan keterampilan seorang guru dalam menciptakan dan memelihara kondisi belajar yang optimal dan mengembalikannya bila terjadi suatu gangguan dalam proses belajar mengajar (Puspitaningrum, 2017). Pengelolaan kelas merupakan seperangkat kegiatan dalam mengembangkan tingkah laku peserta didik yang diinginkan, menghubungkan interpersonal dan iklim sosio emosional yang positif (Aulia \& Sontani, 2018), serta mengembangkan dan mempertahankan organisasi kelas yang efektif (Gidot, Mashudi, \& Matsum, 2013). Pengelolaan kelas merupakan kegiatan guru dalam mengelola kelas yang meliputi kegiatan tingkah laku peserta didik di dalam kelas, mengelola proses kelompok (Asbar, 2018), serta keberhasilan yang didapat oleh seorang guru sangat besar dalam menciptakan kondisi kelas yang efektif, dan indikator dalam proses belajar mengajar dapat berjalan secara efisien (Wati \& Trihantoyo, 2020).

Guru dalam melakukan tugas mengajar di dalam kelas, perlu untuk merencanakan dan menentukan pengelolaan kelas yang efektif (Isnanto, Pomalingo, \& Harun, 2020). Seorang guru dalam pengelolaan kelas harus memperhatikan kondisi dan kemampuan yang dimiliki oleh peserta didik serta materi pelajaran yang akan diajarkan di dalam kelas (Saputra, 2015). Terjadinya proses pembelajaran yang efektif tergantung bagaimana motivasi seorang guru dalam melakukan pengelolaan kelas (Sa'diyah, 2017), pengelolaan kelas yang baik akan membawa dampak yang positif pada saat proses belajar mengajar sedang berlangsung (Puspitaningrum, 2017).

Tugas dan peran demikian, berimplikasi pada persyaratan yang harus dimiliki oleh guru yang profesional. Persyaratan tersebut adalah (I) dasar ilmu yang kuat sebagai perwujudan masyarakat teknologi dan masyarakat ilmu pengetahuan di abad 2I, (2) penguasaan kiat-kiat profesi berdasarkan riset dan praksis pendidikan, dan (3) pengembangan kemampuan profesional berkesinambungan antara LPTK dan praktik pendidikan (Mujianto, 2014). Sebagai upaya untuk memenuhi semua persyaratan guru yang profesional tersebut, Fakultas Keguruan dan Ilmu Pendidikan Universitas Muhammadiyah Malang diberi amanah untuk menyelenggarakan Program Pendidikan Profesi Guru (PPG) Prajabatan Bersubsidi Bidang Studi Bahasa Indonesia. Program PPG dicapai melalui kegiatan pengemasan materi bidang studi untuk pembelajaran yang mendidik, dan praktik pengalaman lapangan (PPL). Praktik Pengalaman Lapangan PPG bertujuan untuk memantapkan penguasaan berbagai kompetensi yang harus dimiliki guru profesional. Dengan demikian, pelaksanaan PPL PPG perlu dilakukan dengan menerapkan prinsip 
berkelanjutan, terstruktur, dan relevan, sehingga program ini dapat menjadi wahana peserta PPG untuk memperoleh kompetensi guru yang profesional. Praktik Pengalaman Lapangan merupakan suatu kegiatan yang wajib ditempuh oleh peserta PPG Bersubsidi.

Program ini memberikan kesempatan kepada calon guru untuk mendalami dan memantapkan kompetensinya sebagai guru bidang studi. Pengalaman belajar selama mengikuti program ini mendukung ketercapaian kompetensi: (I) pengembangan kurikulum dan pembelajaran bidang studi secara kreatif dan inovatif, (2) perencanaan pembelajaran yang mendidik, (3) pelaksanaan pembelajaran yang mendidik, (4) penilaian proses dan hasil belajar, dan (5) pelaksanaan kaidah-kaidah penelitian tindakan kelas (PTK) (Ismail, 20I0). Dengan demikian, calon guru dikatakan memperoleh kompetensi guru yang profesional jika memiliki kelima kompetensi tersebut, khususnya kompetensi melaksanakan pembelajaran yang mendidik melalui kemampuan mengelola kelas (Mansyur \& Akidah, 2018).

Kegiatan observasi dan pencatatan untuk melakukan analisis terhadap pengelolaan kelas yang dilakukan calon guru dalam penelitian ini, diharapkan dapat memberikan gambaran kemampuan calon guru dalam mengelola kelas (Isnanto et al., 2020). Kemampuan mengelola kelas tersebut berkenaan dengan strategi calon guru dalam menciptakan dan mempertahankan suasana (kondisi) kelas agar kegiatan pembelajaran dapat berlangsung secara efisien (Aulia \& Sontani, 2018), karena kondisi yang menguntungkan di dalam kelas merupakan prasyarat utama bagi terjadinya proses belajar mengajar yang efektif (Warsono, 2016). Pembelajaran yang efektif akan membawa hasil belajar peserta didik sesuai harapan pendidik melalui pendekatan yang digunakan calon guru dan keterampilan yang ditunjukkan calon guru dalam pengelolaan kelas (Minsih, 2018). Lebih lanjut, gambaran kemampuan ini merupakan indikasi kompetensi pedagogik calon guru, yaitu kemampuan melaksanakan interaksi atau mengelola proses belajar-mengajar, sesuai dengan kondisi belajar peserta didik (Gidot et al., 2013; Ismail, 2010; Rohmad, 2015).

Dengan memperhatikan latar belakang di atas, maka penelitian ini difokuskan pada perpaduan pendekatan, strategi, dan teknik pengelolaan kelas yang digunakan calon guru dalam PPL PPG Prajabatan Bersubsidi Bidang Studi Bahasa Indonesia di SMAN 7 Malang. Melalui fokus tersebut, penelitian ini pada gilirannya diharapkan dapat memberikan kontribusi pada konsep pengembangan teknologi pengelolaan kelas yang membutuhkan kompetensi komunikatif guru dalam menciptakan dan mempertahankan suasana (kondisi) kelas agar kegiatan pembelajaran dapat berlangsung secara efisien.

Kondisi yang dimaksud adalah kondisi yang dapat menumbuhkan sikap antusias dan motivasi peserta didik dapat diwujudkan dengan beberapa hal. Hal tersebut adalah menggunakan metode pengajaran dan kegiatan belajar yang beragam, menjadikan peserta didik sebagai peserta aktif (Ramli, 20I5), memberikan tugas yang proporsional, realistis, dan sesuai dengan materi belajar, menciptakan suasana kelas yang kondusif (Saputra, 2015), melibatkan diri untuk membantu peserta didik mencapai hasil belajar, memberikan petunjuk kepada peserta didik agar sukses dalam belajar, memberikan penghargaan kepada peserta didik (Maghfiroh, 2019), menciptakan aktivitas yang melibatkan seluruh peserta didik di dalam kelas, menghindari penggunaan ancaman (Hendriana, 2018). Penelitian ini diharapkan membawa kebaruan dalam hal subjek dan fokus penelitian. Subjek penelitian ini adalah calon guru peserta Praktik Pengalaman Lapangan (PPL) Pendidikan Profesi Guru (PPG) Prajabatan dengan fokus penelitian pada pendekatan, strategi, dan teknik pengelolaan kelas. Penelitian pengelolaan kelas yang pernah dilakukan tidak menghadirkan subjek dan fokus demikian.

Penelitian Zahroh (2015) lebih mengedepan interaksi antara guru dan peserta didik. Hasil penelitian yang diperoleh menyimpulkan bahwa kondisi belajar dapat berjalan dengan optimal dan tercapai jika guru mampu mengatur peserta didik dan sarana pembelajaran serta mengendalikannya dalam suasana yang menyenangkan untuk mencapai tujuan pembelajaran. Hubungan yang terjalin baik antara guru dan peserta didik merupakan syarat penting keberhasilan dalam proses belajar mengajar. Proses pembelajaran dapat terjadi apabila di dalam kelas terjadi interaksi antara guru dan peserta didik, interaksi yang baik di dalam kelas akan menjadikan proses pembelajaran berjalan secara efektif. 
Penelitian Pamela (2019) berorientasi pada keterampilan guru dalam mengelola kelas. Guru sebagai pemegang kunci utama pembelajaran harus dapat mengelola kelas dengan baik. Peran guru tidak hanya membuat rencana pembelajaran, menyampaikan materi dan memberi nilai pada peserta didik saja, tetapi guru harus membangun nilai-nilai pada peserta didiknya. Guru sebagai pendidik dan pengasuh harus mampu mengubah karakter peserta didiknya, dari tingkah laku negatif menjadi tingkah laku positif melalui keterampilan mengelola jelas. Hasil penelitian menunjukkan tentang strategi guru dalam mengelola kelas yang kondusif di sekolah dasar bahwa dalam pengelolaan kelas sudah kondusif. Hal ini dibuktikan dengan keadaan ruang kelas yang tertata rapi dan baik dengan karya peserta didik dan mengutamakan keaktifan peserta didik selama proses belajar mengajar berlangsung. Oleh karena itu, pengelolaan kelas oleh guru berpengaruh terhadap hasil belajar peserta didik (Aulia \& Sontani, 2018).

Adapun penelitian yang lebih difokuskan pada strategi guru dalam mengelola kelas di sekolah dasar dilakukan oleh (Chan, Kurniawan, Herawati, Efendi, \& Mulyani, 2019). Peneitian tersebut menyimpulakn bahwa strategi guru dalam mengelola kelas di sekolah adalah dengan membuat kelas penuh dengan karya-karya peserta didik, mengutamakan keaktifan peserta didik selama proses belajar mengajar berlangsung, menggunakan pendekatan keterampilan dalam pembelajaran agar peserta didik dapat menguasai keterampilan dalam mengelola kelas, dengan melakukan rolling pengaturan tempat duduk peserta didik yang sudah mampu mengusai pembelajaran dipindahakan ke tempat duduk belakang, sedangkan peserta didik yang belum menguasai pembelajaran dipindahkan duduk di depan agar lebih fokus pada materi yang disampaikan, menciptakan media pembelajaran dari keterampilan peserta didik.

\section{METODE}

\section{Pendekatan dan Jenis Penelitian}

Pendekatan yang digunakan dalam penelitian ini merupakan pendekatan kualitatif, karena data yang dihasilkan dalam bentuk deskripsi atau uraian detail. Pendekatan kualitatif suatu proses inkuiri pemahaman berdasarkan pada tradisi-tradisi metodologis yang jelas. Peneliti membangun sebuah gambar kompleks yang holistik, menganalisis kata-kata, melaporkan pandangan-pandangan informan secara detail, dan melakukan studi secara alamiah (Ahmadi, 20I4). Penelitian ini menggunakan pendekatan kualitatif karena peneliti ingin mengetahui secara menyeluruh mengenai pengelolaan kelas pada saat proses pembelajaran sedang berlangsung. Peneliti bertindak sebagai pengamat langsung dalam proses penelitian, penelitian ini juga dilakukan untuk mendeskripsikan pengelolaan kelas dalam pembelajaran yang tidak dapat dikuantifikasikan.

Jenis penelitian ini merupakan jenis penelitian studi kasus, merupakan kajian yang rinci tentang satu latar, subjek tunggal, satu tempat penyimpanan dokumen, dan suatu peristiwa tertentu. Studi kasus dapat meliputi persoalan yang luar biasa, seorang penulis studi kasus dapat saja menyeleksi data yang tersedia yang pada hakikatnya semua yang diinginkan dapat digambarkan (Ahmadi, 20I4). Penelitian ini mengambil jenis penelitian studi kasus karena memberikan deskripsi yang padat mengenai pengelolaan kelas pada PPL PPG Prajabatan Bersubsidi Bidang Studi Bahasa Indonesia. Peneliti juga menyajikan sebuah gambar/foto yang dapat dipercaya dalam proses pengelolaan kelas pada saat pembelajaran berlangsung. Peneliti juga dapat mendeskripsikan data secara mendalam tentang pengelolaan kelas dalam proses belajar mengajar.

\section{Subjek Penelitian}

Subjek penelitian ini adalah calon guru peserta Praktik Pengalaman Lapangan (PPL) Pendidikan Profesi Guru (PPG) Prajabatan Bidang Studi Bahasa Indonesia di SMA Negeri 7 Malang sejumlah 7 orang. Subjek penelitian tersebut diamati dan dicatat segala aktivitas pembelajarannya pada saat praktik pengelolaan kelas ketika melaksanakan tugas mengajar semester genap 2018/2019, baik mengajar terbimbing yang dimulai tanggal I2 Januari sampai dengan I2 Februari 2019 maupun mengajar mandiri yang dimulai tanggal I3 Februari sampai dengan 20 April 2019 di Kelas X MIPA I, MIPA 2, MIPA 3, dan MIPA 4. 


\section{Data dan Sumber Data}

Penelitian ini mempunyai dua jenis data, yaitu data tuturan dan data catatan lapangan. Data tuturan dalam penelitian ini berupa tuturan calon guru ketika masuk dalam aktivitas pengelolaan kelas pada saat melaksanakan tugas mengajar. Adapun data catatan lapangan terdiri atas dua jenis, yaitu data catatan lapangan deskriptif dan reflektif. Data catatan lapangan deskriptif berisi tentang (a) rekonstruksi interaksi verbal dalam proses pembelajaran di kelas, dan (b) perilaku calon guru dan peserta didik pada saat terjadi interaksi belajar-mengajar di kelas. Data catatan lapangan reflektif berisi tentang wujud tuturan calon guru dan gambaran tentang kondisi belajar peserta didik. Kondisi belajar yang dimaksud adalah kondisi yang dapat menumbuhkan sikap antusias dan motivasi peserta didik. Dalam penelitian ini kondisi belajar peserta didik yang dimaksud adalah pendekatan, strategi, dan teknik pengelolaan kelas yang digunakan calon guru.

Data tersebut diperoleh dari sumber data yang berupa interaksi verbal bersemuka antara calon guru dan peserta didik dalam proses pembelajaran di kelas. Dalam interaksi verbal tersebut, pendekatan, strategi, dan teknik pengelolaan kelas ditunjukkan calon guru dalam mengelola interaksi belajar-mengajar pada pembelajaran di kelas dapat diidentifikasi. Dalam hal ini data diberi kode dengan unsur-unsur berikut.

a. Tempat pengelolaan kelas, yaitu X MIPA I, X MIPA 2, X MIPA 3, dan X MIPA 4.

b. Tahapan tugas mengajar, yaitu terbimbing (MT) dan mandiri (MM).

c. Aspek penelitian, yang meliputi (P) pendekatan pengelolaan kelas, (S) strategi pengelolaan kelas, dan (T) teknik pengelolaan kelas disertai urutan tuturan calon guru, misalnya: PI, KI, SI, dan seterusnya.

\section{Teknik Pengumpulan Data} berikut:

Adapun teknik yang digunakan untuk mengumpulkan data dalam penelitian ini dengan cara sebagai

\section{Observasi}

Observasi sebagai suatu periode interaksi sosial yang intensif antara peneliti dan subjek dalam suatu lingkungan tertentu (Ahmadi, 20I4). Observasi dilakukan untuk menjaring data berupa hasil pelaksanaan pembelajaran. Observasi dilakukan oleh peneliti untuk masing-masing subjek sebanyak $3 x$ pertemuan, $I x$ pertemuan pada saat tugas mengajar terbimbing dan $2 x$ pertemuan pada saat tugas mandiri. Jadi total observasi di dalam kelas sebanyak 2I pertemuan. Observasi pada kegiatan pembelajaran Bahasa Indonesia difokuskan pada aktivitas pengelolaan kelas yang dilakukan oleh guru di dalam kelas. Observasi dalam penelitian ini dilakukan dengan cermat dan teliti agar hasil yang didapatkan sesuai dengan yang diperlukan dalam penelitian. Observasi dilakukan dari awal pembelajaran hingga pembelajaran berakhir dengan cara membuat rekaman gambar dan suara dari interaksi verbal bersemuka antara calon guru dan peserta didik dalam proses pembelajaran di kelas dengan menggunakan kamera perekam, di samping melakukan pencatatan untuk beberapa aktivitas yang unik.

\section{Dokumentasi}

Pengumpulan data menggunakan dokumentasi adalah pengumpulan data dengan cara menghimpun dan menganalisis dokumen-dokumen, baik dokumen tertulis, gambar, dan elektronik. Adapun dalam penelitian ini, dokumentasi digunakan untuk memperoleh data yang berkenaan dengan persiapan mengajar calon guru, baik berupa pedoman maupun rancangan pembelajaran Bahasa Indonesia di SMA Negeri 7 Malang. Dokumen tersebut adalah Panduan PPL PPG serta Silabus dan RPP Bahasa Indonesia SMA/MA kelas X yang menjadi rujukan pelaksanaan pembelajaran dari awal pembelajaran hingga pembelajaran berakhir.

\section{Teknik Analisis Data}


Analisis data merupakan suatu pencarian pola-pola dalam data, yaitu perilaku yang muncul, objekobjek, atau badan pengetahuan. Analisis data merupakan suatu proses penyelidikan dan pengaturan secara sistematis transkrip wawancara, catatan lapang, dan material-material lain yang dikumpulkan untuk meningkatkan pemahaman (Ahmadi, 20I4). Langkah-langkah analisis penelitian kualitatif bisa berbeda antara satu penelitian dengan penelitian yang lain karena pengalaman berlangsungnya penelitian tidak sama. Langkah-langkah analisis data menurut Miles \& Huberman (dalam Ahmadi, 20I4) adalah data reduction, data display, dan conclusions drawing/verifying.

Mereduksi data berarti merangkum, memilih hal-hal yang pokok dan memfokuskan pada hal-hal yang penting dan membuang data yang tidak diperlukan. Data yang telah direduksi akan memberikan gambaran yang jelas. Pada saat proses reduksi data peneliti mengumpulkan semua data tentang pengelolaan kelas. Peneliti mengelompokkan data yang ditemukan selama proses penelitian berlangsung dan difokuskan sesuai dengan masalah yang telah dirumuskan.

Menyajikan data adalah mengorganisasi dan menyusun data secara sistematis. Menyajikan data secara sistematis dapat memudahkan untuk memahami apa yang terjadi dan dapat melanjutkan rencana tahapan kerja selanjutnya yang telah dipahami. Penyajian data ini dapat dilakukan dalam bentuk uraian singkat yang bersifat deskriptif. Pada penelitian ini, peneliti menyajikan data tentang pengelolaan kelas, baik data tuturan maupun data catatan lapangan sesuai dengan hasil observasi dan reduksi data.

\section{HASIL DAN PEMBAHASAN}

Hasil penelitian ini dikembangkan berdasarkan analisis terhadap pendekatan, strategi, dan teknik pengelolaan kelas. Melalui ketiga hal tersebut, maka diharapkan akan didapatkan gambaran yang lebih konkret mengenai keterampilan calon guru dalam mengelola kelas yang ditunjukkan dalam Praktik Pengalaman Lapangan (PPL) Pendidikan Profesi Guru (PPG) Prajabatan Bidang Studi Bahasa Indonesia di SMA Negeri 7 Malang.

\section{Pendekatan, Strategi, dan Teknik Pengelolaan Kelas pada Kegiatan Awal Pembelajaran}

Pada awal praktik mengajar, calon guru di kegiatan awal pembelajaran menggunakan pendekatan, strategi, dan teknik pengelolaan kelas untuk menyiapkan mental peserta didik agar siap memasuki persoalan yang akan dibicarakan. Di samping itu, juga menyiapkan mental untuk menimbulkan minat dan pemusatan perhatian peserta didik terhadap apa yang akan dipelajari dalam kegiatan pembelajaran. Pendekatan pengelolaan kelas yang digunakan calon guru agar peserta didik siap memasuki persoalan yang akan dibicarakan adalah pendekatan modifikasi perilaku, sedangkan dalam menyiapkan mental untuk menimbulkan minat dan pemusatan perhatian peserta didik terhadap apa yang akan dipelajari calon guru menggunakan pendekatan iklim sosio-emosional. Dalam pelaksanaannya, pendekatan modifikasi perilaku tersebut tidak berdiri sendiri, tetapi dipadu dengan menggunakan strategi pengelolaan kelas yang menunjang, yaitu strategi bertanya. Adapun pendekatan iklim sosio-emosional digunakan calon guru tanpa strategi tertentu, namun langsung menerapkannya melalui teknik preventif.

Pada akhir praktik mengajar, pendekatan, strategi, dan teknik guru lebih bervariasi. Di kegiatan awal pembelajaran menggunakan pendekatan modifikasi perilaku, pendekatan otoriter, dan pendekatan permisif, yang dipadukan dengan strategi bertanya, strategi umpan balik, dan strategi belajar kelompok. Adapun strategi umpan balik, dan strategi belajar kelompok diterapkan guru melalui teknik preventif.

Pendekatan modifikasi perilaku dan pendekatan otoriter digunakan calon guru agar peserta didik siap memasuki persoalan yang akan dibicarakan, sedangkan pendekatan permisif digunakan guru untuk menumbuhkan minat dan perhatian peserta didik terhadap pembelajaran. Dalam hal ini untuk mendukung pemakaian pendekatan modifikasi perilaku dan pendekatan otoriter guru menerapkannya melalui strategi bertanya. Adapun pendekatan permisif diterapkan calon guru melalui pemakaian strategi umpan balik dan strategi belajar kelompok. Dalam hal ini menumbuhkan minat dan perhatian peserta didik terhadap pembelajaran, strategi umpan balik dan strategi belajar kelompok diterapkan guru dengan menggunakan teknik preventif. 


\section{Pendekatan, Strategi, dan Teknik Pengelolaan Kelas pada Kegiatan Inti Pembelajaran}

Kegiatan inti pembelajaran merupakan kegiatan penyampaian materi pembelajaran oleh calon guru dan diikuti interaksi belajar-mengajar dalam rangka pemberian dan pembahasan tugas-tugas peserta didik, baik dilakukan secara berkelompok maupun secara individu. Untuk menerapkan keterampilan dasar mengajar yang berupa dorongan terhadap partisipasi peserta didik. Interaksi belajar-mengajar yang terjadi di dalamnya dapat terjadi antara guru dan peserta didik, guru dan kelompok peserta didik, dan di antara peserta didik itu sendiri. Keterampilan memberikan dorongan terhadap partisipasi peserta didik meliputi memberikan tuntunan pada peserta didik, memberikan pengarahan sederhana, dan pemusatan perhatian agar murid dapat memberikan jawaban yang benar.

Pada awal praktik mengajar, calon guru di kegiatan inti pembelajaran menggunakan pendekatan, strategi, dan teknik pengelolaan kelas untuk memberi dorongan terhadap partisipasi peserta didik agar peserta didik lebih giat berpartisipasi dalam interaksi belajar mengajar. Pendekatan pengelolaan kelas yang digunakan calon guru untuk memberikan tuntunan dan pengarahan sederhana pada peserta didik adalah pendekatan modifikasi perilaku dan pendekatan otoriter. Adapun untuk memusatkan perhatian peserta didik agar murid dapat memberikan jawaban yang benar, guru menggunakan pendekatan iklim sosioemosional, pendekatan group proses, dan pendekatan permisif.

Pendekatan pengelolaan kelas yang digunakan calon guru untuk memberikan tuntunan dan pengarahan sederhana pada peserta didik direalisasi guru dengan menggunakan strategi bertanya dan strategi umpan balik. Di sisi lain, untuk merealisasi pendekatan pengelolaan kelas yang digunakan untuk memusatkan perhatian peserta didik, guru menggunakan strategi belajar kelompok. Ketiga strategi tersebut diterapkan guru dengan menggunakan teknik preventif.

Pada akhir praktik mengajar, calon guru tidak lagi menggunakan pendekatan modifikasi perilaku, tetapi hanya menggunakan pendekatan otoriter untuk memberikan tuntunan dan pengarahan sederhana pada peserta didik. Adapun untuk memusatkan perhatian agar peserta didik dapat memberikan jawaban yang benar, calon guru menggunakan pendekatan iklim sosio-emosional, pendekatan group proses, dan pendekatan permisif dengan indikator yang lebih bervariasi. Kevariasian indikator tersebut didukung oleh penggunaan tiga strategi pengelolaan kelas, yaitu strategi bertanya dan strategi umpan balik untuk memberikan tuntunan dan pengarahan sederhana pada peserta didik, serta strategi belajar kelompok untuk memusatkan perhatian agar peserta didik dapat memberikan jawaban yang benar dengan indikator yang lebih bervariasi. Kevariasian indikator strategi tersebut diterapkan guru dengan teknik yang lebih bervariasi dibanding waktu awal praktik mengajar, karena selain menggunakan teknik preventif untuk memberikan tuntunan dan pengarahan sederhana pada peserta didik, calon guru juga menggunakan teknik kuratif untuk memusatkan perhatian peserta didik.

\section{Pendekatan, Strategi, dan Teknik Pengelolaan Kelas pada Kegiatan Akhir Pembelajaran}

Dalam kegiatan akhir pembelajaran calon guru menerapkan keterampilan dasar mengajar yang berupa siasat menutup pembelajaran. Siasat menutup pembelajaran ialah usaha atau kegiatan calon guru untuk mengakhiri kegiatan belajar-mengajar. Di kegiatan akhir pembelajaran menggunakan pendekatan dan strategi pengelolaan kelas untuk menutup pembelajaran, yang meliputi (I) merangkum atau membuat garis-garis besar persoalan yang baru saja dibahas/dipelajari, sehingga peserta didik memperoleh gambaran yang jelas tentang makna serta esensi dari pokok persoalan yang baru saja diperbincangkan; (2) mengonsolidasikan perhatian peserta didik terhadap hal-hal yang pokok dalam pembicaraan/pembelajaran (refleksi); dan (3) mengorganisasikan semua kegiatan sebagai suatu kebulatan (tindak lanjut), agar informasi yang telah diterimanya dapat membangkitkan minat dan kemampuannya pada masa-masa mendatang dalam kelanjutan proses belajar-mengajar maupun penghidupannya.

Dalam awal praktik mengajar pada kegiatan akhir ini, guru tidak menggunakan pendekatan dan strategi yang bervariasi. Dalam merangkum atau membuat garis-garis besar persoalan yang baru saja dibahas/dipelajari calon guru langsung merealisasikannya dengan menggunakan strategi bertanya. Setelah 
itu, calon guru mengonsolidasikan perhatian peserta didik terhadap hal-hal yang pokok dalam pembicaraan/pembelajaran (refleksi) dengan menggunakan pendekatan iklim sosio-emosional. Pendekatan dan strategi pada akhir kegiatan tersebut digunakan guru tanpa penyertaan teknik pembelajaran tertentu.

Tidak jauh berbeda dengan di awal praktik mengajar, pada akhir praktik mengajar di kegiatan akhir ini, calon guru di kegiatan akhir pembelajaran menggunakan satu pendekatan dan satu strategi pengelolaan kelas untuk untuk menutup pembelajaran. Pemilihan calon guru terhadap pendekatan pengelolaan kelas memiliki kesamaan, yaitu menggunakan pendekatan iklim sosio-emosional untuk merangkum atau membuat garis-garis besar persoalan yang baru saja dibahas/dipelajari, sehingga peserta didik memperoleh gambaran yang jelas tentang makna serta esensi dari pokok persoalan yang baru saja diperbincangkan. Namun demikian, untuk merealisasikannya, guru menggunakan strategi yang berbeda dengan siasat yang berbeda. Dalam hal ini, guru memilih strategi umpan balik untuk mengorganisasikan semua kegiatan sebagai suatu kebulatan (tindak lanjut), agar informasi yang telah diterima peserta didik dapat membangkitkan minat dan kemampuannya pada masa-masa mendatang dalam kelanjutan proses belajar-mengajar maupun penghidupannya.

\section{PEMBAHASAN}

Pada kegiatan inti calon guru menggunakan pendekatan, strategi, dan teknik yang lebih bervariasi dibanding pada kegiatan awal dan kegiatan penutup. Kevariasian pada kegiatan inti tersebut tidak terlepas dari sudut pandang guru terhadap proses pembelajaran berdasarkan pembagian peran subjek dalam pembelajaran. Pembagian peran subjek ini menyangkut bagaimana guru memosisikan peran dirinya di tengah para peserta didik dalam interaksi belajar mengajar, sehingga calon guru mampu menciptakan lingkungan belajar yang efektif dan efisien, sehingga hasil belajar mencapai tingkat yang optimal. Dalam hal ini peran yang harus diposisikan oleh calon guru dalam pembelajaran sangat dipengaruhi oleh fungsi guru sebagai manajer kelas.

Posisi peran inilah yang kemudian melahirkan pembagian peran subjek pembelajaran melalui pemilihan pendekatan yang bervariasi, dan lebih mengutamakan pendekatan iklim sosio-emosional, sehingga melahirkan interaksi pembelajaran yang memungkinkan peserta didik untuk menunjukkan kemampuan yang optimal. Kevariasian peran subjek belajar ini menjadikan guru memiliki peran sebagai pengamat, pendamping, pembina, dan pemimpin dalam iklim atau suasana emosional dan hubungan sosial yang positif dalam kelas. Artinya, ada hubungan yang baik dan positif antara guru dengan peserta didik, atau antara peserta didik dengan peserta didik. Di sini guru adalah kunci dalam pembentukan hubungan pribadi itu, dan peranannya adalah menciptakan hubungan pribadi yang sehat.

Orientasi peran yang demikian, menjadikan guru lebih mengutamakan interaksi pembelajaran melalui bertanya dan memberi penguatan untuk mendorong peserta didik mendemostrasikan kinerja (perfomance) sebagai hasil belajar. Dampaknya terhadap peserta didik, di antaranya peserta didik dapat mengatasi masalah dalam konteks baru, berpikir secara benar, mampu beradaptasi dengan cara yang inovatif, dan mereka merasa mendapat penghargaan dalam pembelajaran. Murdoch dan Wilson (dalam Halimah, 2017) mengemukakan jika peserta didik merasa dihargai di kelasnya, maka peserta didik akan berani mengambil resiko, dan memiliki motivasi untuk berpikir, melakukan, dan membuat keputusan untuk belajar dengan penuh tanggung jawab, sehingga perbedaan individu mendapat perhatian yang memadai, sesuai dengan kebutuhan perkembangan setiap peserta didik.

Perhatian terhadap adanya perbedaan individu dalam pembelajaran ini, tidak berarti mengarah kepada sistem pembelajaran individual, tetapi merupakan penyediaan alternatif yang memungkinkan terpenuhinya kebutuhan perkembangan peserta didik yang terdapat dalam kelas. Dalam hal ini, calon guru membuat variasi melalui pembelajaran kelompok-kelompok kecil selain pembelajaran perorangan. Dengan adanya variasi seperti ini, sangat memberikan peluang yang lebih besar bagi terpenuhinya kebutuhan setiap peserta didik. Dengan demikian, munculnya tingkah laku anak yang dapat mengganggu 
kegiatan pembelajaran dapat diantisipasi dan dicegah oleh guru. Hal ini disebabkan, pendekatan dan strategi yang bervariasi menuntut calon guru untuk memiliki sejumlah sikap.

Pertama, calon guru memiliki sikap terbuka. Sikap terbuka dalam pencegahan perilaku peserta didik yang tidak diharapkan dalam kelas merupakan sikap calon guru yang penting untuk menunjukkan keakraban hubungannya dengan peserta didik. Dengan menciptakan suasana keterbukaan, anak-anak benar-benar merasa bebas dan lelausa untuk mengemukakan pendapatnya serta penuh keyakinan bahwa guru akan selalu mendengarkan dan memperhatikan pendapatnya. Kedua, calon guru memiliki sikap menerima dan menghargai peserta didik sebagai manusia. Sikap menerima dan menghargai peserta didik sebagai manusia berpengaruh kepada perkembangan anak. Anak tidak akan merasa rendah diri dan malu, karena guru memperlakukannya dengan cara yang tidak membeda-bedakan. Dalam hal ini anak mendapat perlakuan yang sama dari calon guru. Ketiga, calon guru memiliki sikap demokratis. Sikap demokratis ditunjukkan calon guru dengan berusaha menempatkan perannya sebagai pengarah dan pembimbing dalam proses pembelajaran. Berbicara dengan suara ramah, membimbing peserta didik, menggunakan kata-kata ajakan, menolong peserta didik, dan membagi tanggung jawab secara bersama adalah beberapa contoh upaya guru untuk menciptakan suasana demokratis di dalam kelas. Dari sini peserta didik akan belajar bijaksana mengambil keputusan, belajar menanggung konsekuensi dari perbuatannya sendiri, dan bertanggung jawab terhadap aturan kelompok yang disepakati bersama. Dalam hal ini usaha yang dilakukan calon guru untuk mengarahkan anak pada tujuan kelompok adalah mengarahkan anak pada tujuan kelas, khususnya tujuan pembelajaran, yang dirumuskan secara realistis dan dikomunikasikan pada anak secara jelas pada kegiatan awal pembelajaran.

\section{SIMPULAN}

Di kegiatan awal pembelajaran menggunakan pendekatan modifikasi perilaku, pendekatan otoriter, dan pendekatan permisif, yang dipadukan dengan strategi bertanya, strategi umpan balik, dan strategi belajar kelompok. Adapun strategi umpan balik, dan strategi belajar kelompok diterapkan guru melalui teknik preventif. Perpaduan antara pendekatan, strategi, dan teknik tersebut digunakan calon guru untuk menyiapkan mental peserta didik agar siap memasuki persoalan yang akan dibicarakan dan untuk menumbuhkan minat dan mengarahkan perhatian peserta didik terhadap apa yang akan dipelajari dalam kegiatan pembelajaran.

Pada kegiatan inti pembelajaran, calon guru menggunakan pendekatan, strategi, dan teknik pengelolaan kelas untuk memberi dorongan terhadap partisipasi peserta didik agar peserta didik lebih giat berpartisipasi dalam interaksi belajar mengajar. Pendekatan pengelolaan kelas yang digunakan calon guru untuk memberikan tuntunan dan pengarahan sederhana pada peserta didik adalah pendekatan modifikasi perilaku dan pendekatan otoriter. Adapun untuk memusatkan perhatian peserta didik agar murid dapat memberikan jawaban yang benar, guru menggunakan pendekatan iklim sosio-emosional, pendekatan group proses, dan pendekatan permisif. Pendekatan pengelolaan kelas yang digunakan calon guru untuk memberikan tuntunan dan pengarahan sederhana pada peserta didik direalisasikan guru dengan menggunakan strategi bertanya dan strategi umpan balik. Di sisi lain, untuk merealisasi pendekatan pengelolaan kelas yang digunakan untuk memusatkan perhatian peserta didik, guru menggunakan strategi belajar kelompok. Ketiga strategi tersebut diterapkan guru dengan menggunakan teknik preventif. Kevariasian pada kegiatan inti tersebut tidak terlepas dari sudut pandang guru terhadap proses pembelajaran berdasarkan pembagian peran subjek dalam pembelajaran. Pembagian peran subjek ini menyangkut bagaimana guru memosisikan peran dirinya di tengah para peserta didik dalam interaksi belajar mengajar, sehingga calon guru mampu menciptakan lingkungan belajar yang efektif dan efisien, sehingga hasil belajar mencapai tingkat yang optimal.

Pada kegiatan akhir, guru tidak menggunakan pendekatan dan strategi yang bervariasi. Calon guru mengkonsolidasikan perhatian peserta didik terhadap hal-hal yang pokok dalam pembicaraan/pembelajaran (refleksi) dengan menggunakan pendekatan iklim sosio-emosional tanpa strategi tertentu. Dalam merangkum atau membuat garis-garis besar persoalan yang baru saja 
dibahas/dipelajari calon guru langsung merealisasikannya dengan menggunakan strategi bertanya. Juga ketika calon guru mengorganisasikan semua kegiatan sebagai suatu kebulatan (tindak lanjut), langsung memilih strategi umpan balik. Pendekatan dan strategi pada akhir kegiatan tersebut digunakan guru tanpa penyertaan teknik pembelajaran tertentu.

\section{UCAPAN TERIMA KASIH}

Penulis mengucapkan terima kasih kepada Direktorat Penelitian dan Pengabdian Kepada Masyarakat (DPPM) Universitas Muhammadiyah Malang yang telah memberikan dukungan dalam penelitian ini. Penulis juga mengucapkan terima kasih kepada semua pihak yang telah berkontribusi dalam penelitian ini, sehingga penelitian ini dapat terlaksana dan diselesaikan dengan baik.

\section{DAFTAR PUSTAKA}

Ahmadi, R. (20I4). Metodologi penelitian kualitatif. Yogyakarta: Ar-ruzz Media.

Aliyyah, R. R., \& Abdurakhman, O. (2016). Pengelolaan kelas rendah di SD Amaliah Ciawi Bogor. Jurnal Sosial Humaniora, 7(2), 8I-95. doi: http://dx.doi.org/I0.30997/jsh.v7i2.488

Asbar, A. M. (2018). Strategi guru dalam pengelolaan kelas pada pembelajaran pendidikan agama Islam di SMP Negeri 39 Bulukumba. Al Qalam: Jurnal Ilmiah Keagamaan dan Kemasyarakatan, I2(I), 89-II2. doi: http://dx.doi.org/I0.3593I/aq.v0i0.2I

Aulia, R., \& Sontani, U. T. (2018). Pengelolaan kelas sebagai determinan terhadap hasil belajar. Jurnal Pendidikan Manajemen Perkantoran, 3(2), 9-17.

Chan, F., Kurniawan, A. R., Herawati, N., Efendi, R. N., \& Mulyani, J. S. (2019). Strategi guru dalam mengelola kelas di sekolah dasar. International Journal of Elementary Education, 3(4), 439-446. doi: http://dx.doi.org/I0.23887/ijee.v3i4.21749

Daryanto. (2016). Media pembelajaran. Yogyakarta: Gava Media.

Faruqi, D. (2018). Upaya meningkatkan kemampuan belajar siswa melalui pengelolaan kelas. Jurnal Evaluasi, 2(I), 294-3I0. doi: http://dx.doi.org/I0.32478/evaluasi.v2iI.80

Gidot, S., Mashudi, H., \& Matsum, J. H. (2013). Pengaruh kompetensi profesional guru dan minat belajar terhadap hasil belajar akuntansi siswa kelas XI. Jurnal Pendidikan dan Pembelajaran Khatulistiwa, 3(3), I-I4. Retrieved from: https://jurnal.untan.ac.id/index.php/jpdpb/article/view/4836

Habiburrahman, S. (20I5). Hakikat pendidik dan peserta didik dalam Islam. ATTANWIR, I(I), I-5. Retrieved from: https://jurnal.um-palembang.ac.id/index.php/attanwir/article/view/6

Halimah, L. (2017). Keterampilan mengajar, sebagai inspirasi untuk menjadi guru yang excellent di abad ke-2I. Bandung: PT Refika Aditama.

Hendriana, E. C. (20I8). Pengaruh keterampilan guru dalam mengelola kelas terhadap hasil belajar peserta didik di sekolah dasar. JPDI (Jurnal Pendidikan Dasar Indonesia), 3(2), 46-49. doi: http://dx.doi.org/I0.26737/jpdi.v3i2.780

Isbadrianingtyas, N., Hasanah, M., \& Mudiono, A. (2016). Pengelolaan kelas dalam pembelajaran tematik di sekolah dasar. Jurnal Pendidikan: Teori, Penelitian, dan Pengembangan, I(5), 90I-904. doi: http://dx.doi.org/I0.I7977/jp.vIi5.6300

Ismail, M. I. (2010). Kinerja dan kompetensi guru dalam pembelajaran. Lentera Pendidikan: Jurnal Ilmu Tarbiyah dan Keguruan, I3(I), 44-63.

Isnanto, I., Pomalingo, S., \& Harun, M. N. (2020). Strategi pengelolaan kelas di sekolah dasar. Jurnal Pendidikan Glasser, 4(I), 7-24. doi: https:/ / doi.org/I0.32529/glasser.v4iI.392

Maghfiroh, L. (2019). Hakikat pendidik dan peserta didik dalam pendidikan Islam MIDA: Jurnal Pendidikan Dasar Islam, 2(2), 2I-36. Retrieved from: http://ejurnal.unisda.ac.id/index.php/mida/article/view/I573

Mansyur, U., \& Akidah, I. (2018). Peningkatan kompetensi profesional guru Mts DDI Padanglampe Kabupaten Pangkep melalui pelatihan penulisan karya tulis ilmiah. JPPM (Jurnal Pengabdian dan Pemberdayaan Masyarakat), 2(2), 273-278. doi: 10.30595/jppm.v2i2.2589 
Minsih, M. (20I8). Peran guru dalam pengelolaan kelas. Profesi pendidikan dasar, I(I), 20-27. Retrieved from: http://journals.ums.ac.id/index.php/ppd/article/view/6I44

Mujianto, G. (20I4). Pemakaian tuturan imperatif calon guru dalam interaksi belajar mengajar pada pembelajaran mikro di fakultas keguruan dan ilmu pendidikan Universitas Muhammadiyah Malang. Jurnal Humanity, 8(I), I55-I62.

Mustofa, M. (2019). Strategi penanaman nilai-nilai antikorupsi di sekolah dasar. Education and Human Development Journal, 5(I), 43-60. doi: https:/ / doi.org/I0.33086/ehdj.v5iI.I30I

Pamela, I. S. (2019). Keterampilan guru dalam mengelola kelas. Jurnal pendidikan dasar, 3(2), 23-30.

Puspitaningdyah, D. O. (2018). Pengaruh keterampilan mengelola kelas dan keaktifan belajar terhadap hasil belajar IPS SD. Joyful Learning Journal, $7(\mathrm{I}), 39-47$. doi: https://doi.org/I0.I5294/jli.v7iI.24I88

Puspitaningrum, E. (2017). Kemampuan guru dalam pengelolaan kelas di SD Negeri Minomartani 2. Basic Education, 6(I), 28-39. Retrieved from: http://journal.student.uny.ac.id/ojs/ojs/index.php/pgsd/article/view/6604

Ramli, M. (2015). Hakikat pendidik dan peserta didik. Tarbiyah Islamiyah: Jurnal Ilmiah Pendidikan Agama Islam, 5(I), 6I-85. doi: http://dx.doi.org/I0.I8592/jt\%20ipai.v5iI.I825

Rohmad, M. A. (20I5). Pengelolaan kelas bekal calon guru berkelas. Yogyakarta: Kaukaba Dipantara.

Sa'diyah, M. A. S. H. (2017). Model pengelolaan kelas dalam pembelajaran PAI di SD Riyadlul Arkham Tembong Plintahan Pandaan. Al-Murabbi, 2(2), 29I-3I0. Retrieved from: https://jurnal.yudharta.ac.id/v2/index.php/pai/article/view/608/499

Saputra, M. I. (2015). Hakekat pendidik dan peserta didik dalam pendidikan Islam. Al-Tadzkiyyah: Jurnal Pendidikan Islam, 6(2), 23I-25I. doi: https://doi.org/I0.24042/atjpi.v6i2.I5I6

Sudjalil, S., \& Mujianto, G. (2017). Strategi imperatif verbal guru dalam penanaman nilai karakter pada siswa SMA unggulan di Malang. Jurnal Linguistika, 24(46), 13-22. Retrieved from: https://www.neliti.com/publications/229682/strategi-imperatif-verbal-guru-dalam penanaman-nilai-karakter-pada-siswa-sma-ung

Warsono, S. (2016). Pengelolaan kelas dalam meningkatkan belajar siswa. Manajer Pendidikan, IO(5), $469-476$. Retrieved from: https://ejournal.unib.ac.id/index.php/manajerpendidikan/article/viewFile/I298/I093

Wati, A. R. Z., \& Trihantoyo, S. (2020). Strategi pengelolaan kelas unggulan dalam meningkatkan prestasi belajar siswa. JDMP (Jurnal Dinamika Manajemen Pendidikan), 5(I), 46-57. doi: http://dx.doi.org/I0.26740/jdmp.v5nI.p46-57

Yumnah, S. (2018). Strategi dan pendekatan pengelolaan kelas dalam pembelajaran. Jurnal Studi Islam: Pancawahana, I3(I), I8-26. Retrieved http:// ejournal.kopertais4.or.id/tapalkuda/index.php/pwahana/article/view/3196/237I

Zahroh, L. (20I5). Pendekatan dalam pengelolaan kelas. TASYRI': Jurnal Tarbiyah-Syari'ah Islamiyah, 22(2), I75-I89. Retrieved from: file:///C:/Users/LENOVO/Downloads/I550Article\%20Text-4230-I-I0-20160404.pdf 